\title{
Border Reopening and its Impact on Nigeria Economy a Marketing Perspectives
}

\author{
1. Emmanvitalis, Emeka Ifediba PhD \\ Marketing Department, Madonna University Nigeria, \\ Okija Campus, Nigeria
}

\author{
2. Ogochukwu Nwangene PhD \\ Marketing Department, Odumegwu Ojukwu \\ University, Igbariam, Nigeria
}

DOI: 10.47760/cognizance.2021.v01i09.002

\begin{abstract}
One of the most vital border regions in West Africa is the frontier between Nigeria and Benin. The global outbreak of Covid-19 leads to nation and wide lockdown in many countries. The countries and areas that have passed the worst phase of the outbreak or were able to prevent an internal outbreak are eager to reopen as prolonged lockdown could cause damages to the economy and social structure. The Nigeria government has approved the opening of its land borders on December 2020, since its closure on August 2019. This study aimed at determining the impact of border reopening on the Nigeria economy. The study area was Badagry and Apapa Metropolis Lagos State, Nigeria. A random sampling technique was employed, through the use of structured questionnaire on a sample of one hundred and ten (110); artisans (15), traders (50) and farmers (45) were used for data analysis. The Pearson product moment correlation coefficient was used to confirm formulated hypotheses. The study found that the recent border reopening is improving the Nigeria economy and gradually have good significant effect on market prices and in turn increasing the marketing turnover. The study also recommended that there is need to strengthen the border policing and management mechanisms to avoid a relapse into the conditions that led to the closure in the first place.
\end{abstract}

Keywords: Covid-19, Land border closure, Socio-economic development, Economic activity 


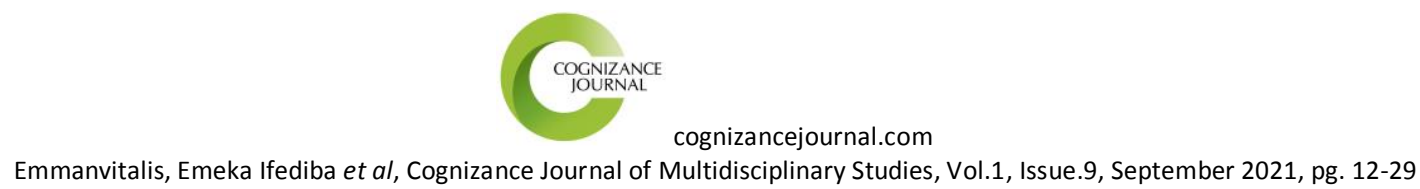

\section{INTRODUCTION}

2020 was an unprecedented year, no thanks to the coronavirus outbreak, as the global economy was suspended in second quarter $\left(\mathrm{Q}_{2}\right)$ and most of third quarter $\left(Q_{3}\right) 2020$ to safeguard human health.

Nigeria which shares boundaries with Benin, Niger, and Cameroon closed all its land borders in order to ensure total control over what comes into the country in October, 2019 (Olatunji, 2019), though that was not the first instance. The cause of this action in the view of the government was the smuggling of rice and other illicit exports of cheaper, subsidised petrol from Nigeria to its neighbours as 10 to 20 percent of Nigeria fuel was smuggled abroad.

Soon after the border closures, Nigerians and trading partners in neighbouring West African countries began asking the Nigerian government to reopen the borders to prevent further hardship, especially as the Covid-19 pandemic began to bite. The countries and areas that have passed the worst phase of the outbreak or were able to prevent an internal outbreak are eager to reopen as prolonged lockdown could cause damages to the economy and social structure.

On $17^{\text {th }}$ December 2020, the Nigeria government approved the recommendation of a presidential committee to reopen the Seme, illela, Maigatari\&Mfun borders. Other land borders were reopened on $31^{\text {th }}$ December in readiness to trading under the Africa Continental Free Trade Area (AFCFTA), which came into effect on $1^{\text {st }}$ January (Kelechukwu, 2021).

\section{Statement of the Problem}

Nigeria has reopened its land borders to trade, but the deep-rooted economic problems that led to the closure in 2019 still needs to be resolved. The Nigeria government should take appropriate measures to curb the inherent challenges which have repercussion on both the citizenry and the economy of Nigeria. 


\section{Objectives of the Study}

1. to determine the impact of border reopening on the Nigeria economy

2. to determine the effect of market prices

\section{Research Questions}

The following research questions will be addressed in this Study;

1. Does border reopening have any significant good effect on market prices?

2. Has border reopening improved the economy of the country?

\section{Literature Review}

Literature review is an important part of a research study as it involves many activities which include identifying, reading, evaluating, describing, summarizing, discussing, citing, and synthesizing various documents with an intention of incorporating them in the study under investigation. This section deals with Conceptual clarification, Theoretical framework and Emperical review.

\section{Conception Clarification}

\section{Overview of Nigeria's Border Closure Policy}

Border closure is a protectionist policy that prevents the movement of goods or people between different jurisdictions with limited or no exceptions associated with this movement (Wikipedia, 2019). Following the worldwide drop in the price of crude oil in 2014, Nigeria's economy declined in 2015 and deteriorated by $1.6 \%$ in 2016 (Bukola, 2018). The economic state of the country further worsened until it fell into a recession in 2018. The fall in the value of the naira as a result of shortages in foreign exchange and the plunge of foreign direct investment caused the government to implement stringent policies. The crippling weight on the oil sector being a major source of the country's income got worse with the oil crisis. Consequent upon these, the government believed 
that running an independent economy will suffice, which has led to the border closure policy.

The recent border closure trend in Nigeria started in August 2019 when the President of Nigeria, President Muhammadu Buhari ordered the closure of Nigeria's land border with Benin, preventing the import of goods (John, 2020). The move was said to be in a bid to curb smuggling of rice staple and associated corruption. Previously, on the 14th of October 2014 Nigeria had ordered the closure of all of its borders with Benin as well as those with all other countries thereby stopping trade flow with its neighbours for same reasons. The goods caught in the ban include rice, poultry birds, frozen foods, weapons and ammunition, bagged cement, second hand clothing and lots more. According to the National Statistic Institute, in 2017, Cameroon imported 728,443 metric tons of rice against a population of about 24 million. Niger imported rice worth $\$ 53.9$ million, about 135 metric tons of rice for a population of 21 million. The same year, Nigeria imported 1.3 million metric tons of rice for a population of over 190 million people (Godwin, 2018). Thus, most rice products imported into border nations were illegally exported through the land borders into the Nigerian territory.

President Muhammadu Buhari's government in effect restricted the import of rice in order to encourage Nigerian rice production. In this light, the policy was implemented as a protectionist policy. This border closure policy has raised a lot of whirlwinds amongst the masses and the international community. Some Nigerians have expressed satisfaction especially those into farming while others have expressed their dissatisfaction especially those into the trade business. 


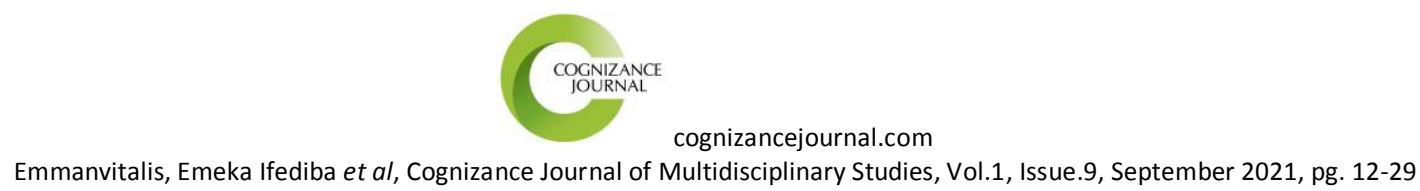

\section{Economic and Infrastructural Capacity of Nigeria}

The economic and infrastructural conditions of any country must be considered and reflect in its economic policies both nationally and internationally. Thus, the big question is whether Nigeria, regarding its economic and infrastructural status, is capable of running an independent supply chain. Although it is not a total witless exercise in light of reducing import expenses, curbing smuggling and tackling insecurity, to run a closed border policy; however, this requires the institution of infrastructural facilities to aid efficient production of otherwise imported goods for the masses. However, the infrastructural facilities and economic condition of the country are not sufficiently buoyant to carry the burden of sole production of its goods. For instance, a ban has been placed on the importation of rice but are there sufficient mills to aid the production of a quantity that would meet the demand of the consumers? Following the implementation of the closed border policy, the price of rice and other commodities skyrocketed. A bag of rice that was previously sold at NGN13, 000 and NGN15,000 skyrocketed to NGN20,000/NGN25,000 an increase rate of about 40\% (Business Day, 2019). Business Day also reports that Nigeria's trade sector has slumped into recession as economies across the nation's land borders remain grounded (Oluwasegun, 2019. According to the reports of the National Bureau of Statistics (NBS), the trade sector shrank by $1.45 \%$ in the third quarter of 2019 from a decline of $0.25 \%$ in the preceding quarter. These factors contribute to the reduction of her comparative advantage and make sole production too much of a burden to carry 


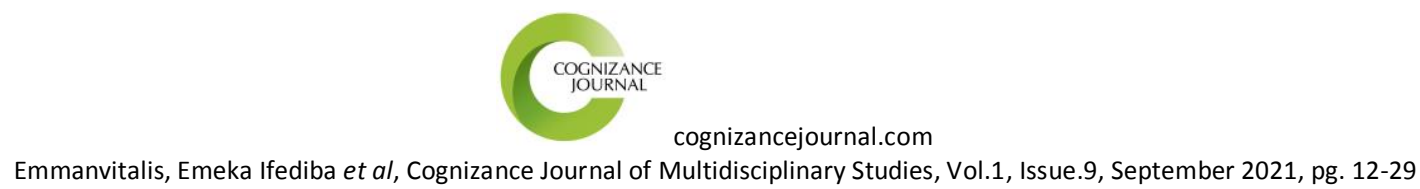

\section{Effect on Local Businesses}

The question also arises as to the effect of this policy on local businesses. What happens to businesses that run on these goods which might not be readily available or are sold at high prices because of monopoly? The cost of running such businesses will definitely increase and the burden will fall back on the citizens and lead to higher cost of living. For instance, a restaurant which used to make use of a bag of rice daily sold at NGN13,000 starts spending NGN20,000 daily on a bag of rice due to the increase in the cost of goods after the border closure, will increase the price per serving. A person who gets satisfied after a serving of NGN100 will have to spend more to get that level of satisfaction in the present time. This is in a country yet to implement the minimum wage for workers. Increase in the price of staple foods especially rice which is one of the most popular foods in the country will make many Nigerians worse off. In free market economies, the existence of market competition takes its toll in reducing lousy products in the market; as such every business is inclined to make good products that can favourably compete in the market. However, a protectionist system like the border closure policy stifles this process. Domestic companies will no longer need to compete with other imported goods resulting in local monopoly, inflation and most times substandard goods. Not only will there be a lack of international competition, but also a slope in innovation, and goods become more expensive. Food or items that do not grow or are not produced simply disappears from the market in the country resulting in accumulation of debt due to the imbalance between money spent on industries and lack of growth. Therefore, while there is a purported benefit, it is only short term and will bring about difficulties in the long run. When such goes on for a long time it will generate an economic problem, in that 


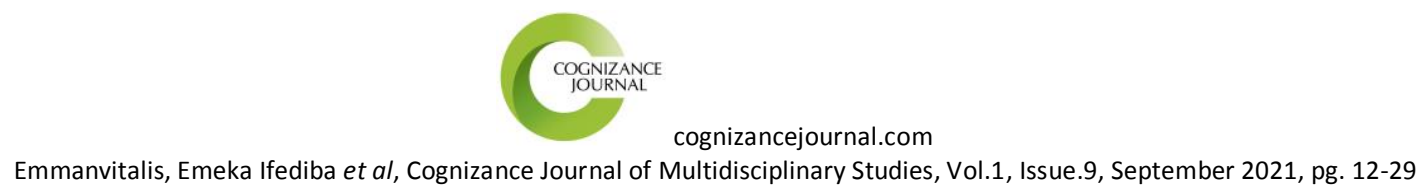

when domestic businesses remain uncompetitive for too long it becomes difficult to reverse protectionist policies (Ryan, 2016).

\section{Unemployment and Trade Loss}

The implementation of the border closure policy not only saw the laying-off of a lot of workers especially in the import and export business, but also in other local businesses as well as significant financial loss to these businesses. Most importers of perishable goods, valued at millions of naira had their consignment of goods trapped in Cotonou for several weeks because the Seme and Idiroko borders were closed without warning, resulting in huge financial loss and debt for those operating on loaned funds. Asides these, a lot of workers and labourers got laid-off thereby increasing unemployment in the society.

\section{Unfair Competition in the Nigerian Market}

Femi Adekoya in a publication of July 11, 2018 stated categorically that in Nigeria's case, unchecked competition, especially from imported goods remains a challenge for the manufacturing sector (Akinkuolie, 2020). Unfair competition in its general sense means that the competitors compete on unequal terms, because favourable or disadvantageous conditions are applied to some competitors but not to others; or that the actions of some competitors actively harm the position of others with respect to their ability to compete on equal and fair terms. From this definition, it is evident that these goods smuggled into Nigeria through the land borders, on which the relevant import duties and tariffs have not been paid, would be sold at a lesser price rate in comparison to legally imported or locally made products. This disparity in price, despite the poor quality of the smuggled goods, creates a favourable condition of competition for same as against the other class of products earlier stated. 
Furthermore, it is a succinct statement of fact that the Nigerian locals have a perceived preference for imported rice over the locally produced ones. Therefore, there is implicit in the trade conditions unfair and more favourable chances of better sale by the sellers of these illegally imported low quality goods. According to the Global Food Security in a review published on March, 2020 , prior to the adoption of the closed border policy in Nigeria, the demand for locally produced rice over imported rice, on a scale of 10 was on a ratio of $2: 8$. However, since the adoption of the policy in 2019 , rice production in Nigeria has grown fast, pushed by the rapid growth in the demand for locally produced rice (Sanya, 2019).

\section{Theoretical framework}

Every substantial phenomenon, is bound to have logical and empirical explanations. It is in such situations that theories prove their utmost value, especially in scholarly endeavors.

\section{Theory of Comparative Advantage}

This work is hinged on the Theory of Comparative Advantage which was discovered and developed by David Ricardo (1772 - 1823). However, other proponents who contributed immensely towards the development of the theory include James Mill (1773 - 1836) and Robert Torrens (1780 - 1864). Ricardo considered two countries like Nigeria and Niger Republic for instance whereby Nigeria produces certain goods or commodities at a cheaper rate and with higher specialisation whereby Niger Republic may equally be specialised in the production of other goods which Nigeria does not produce. This brings the two countries together for international trade probably Cross Border Trade since Nigeria and Niger Republic share boundary together. However, when it is stated 


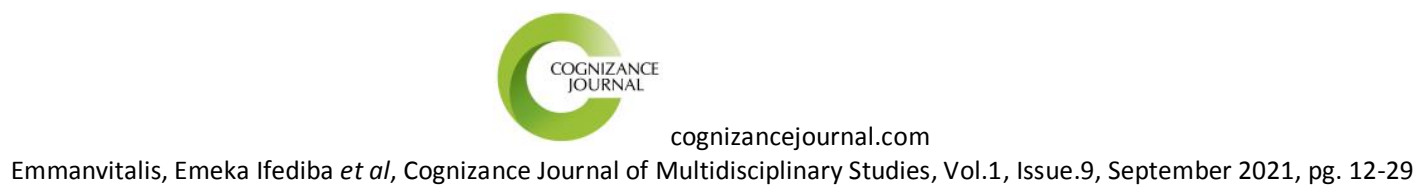

that, international trade depends on the differences in comparative advantage one may explore not absolute cost of production in the two countries.

Therefore, it is good for a country to import commodities from another country where the cost of production of those commodities cost less than it would be at home. This by extension necessitated the trading, transaction and relating with one country by another perhaps Nigeria and Niger Republic. Whereas closing the border between countries will disconnect one from the other.

\section{Empirical Review}

Tony Onoharigho (2020) carried a qualitative research on border reopening which was aimed at investigating how the influx of commodities to the market would drive prices low. The study which was disclosed during an interview with the News Agency of Nigeria, found that the reopening of the nation's borders would facilitate the free flow and movement of goods into the country, and in turn increase the market turnover and money in circulation,

Ajayi et al., (2020) conducted a study on assessment of land border closure on the socio-economic development of people in saki metropolis, Oyo state, Nigeria. The economic development was measured through improved standard of living and level of income. A descriptive Survey design was employed, through the use of structured questionnaire on a sample of one hundred and eighty (180) farmers. One hundred and sixty-six (166) copies of the questionnaire were correctly filled and returned. One hypothesis was formulated and regression analysis was employed in estimating the regression models with the aid of SPSS version 20. The findings revealed that the result from the probability of f-statistic (14.924) and the coefficient of determination (Adjusted $\mathrm{R}^{2}$ ) which values at 0.137 shows that although the model of the research is 
statistically significant; the result indicates that land border closure has a negative effect on the socio-economic lives of people in the study area. Based on the findings, we recommend among other things that the policy of land border closure should be revisited.

\section{Research Methodology}

This chapter discusses the ways and means through which the study was carried out. It also presents the research Area of Study, Source of Data, Sampling Technique. Method of Data Collection, Method of Data Analysis.

\section{Area of Study}

The area of the study cover Badagry and Apapa Metropolis, Lagos state. These formed the population for the study.

\section{Sources of Data}

The researcher employed the use of both the primary and secondary sources of data. Primary sources of data are first-hand information. The data is generated by the researcher for the purpose of the study, primary data collected for this study are questionnaires given to the marketers under study to elicit responses. While that of the secondary data are facts that the researcher collected from already existing sources. The secondary sources from which data were generated are newspapers, magazines, journals, published research work, memo-graphs.

\section{Sampling Techniques}

The simple random sampling technique is employed, giving each member of the population an equal chance. A sample size of 120 persons was selected at random, using Bourley (1998) proportional allocation formula, it was 
distributed as follows: artisans (15), traders (50) and farmers (45). One hundred (110) were used for data analysis

A pre-test was conducted and outcome yield " $\mathrm{r}$ " $=0.92$ indicating a high degree of consistency and reliability. The instrument was 8- term survey questionnaire with a - 5 Likert scale response options of Very Relevant (VR), Relevant(R), No Effect (NE) Irrelevant (I), and Very Irrelevant (VI). The questionnaire was structured in line with the research objectives, questions and hypothesis of the study. The Pearson product moment correlation coefficient was used to confirm formulated hypotheses.

\section{Method of Data Analysis}

The questionnaire was structured in line with the research objectives, questions and hypothesis of the study. The response gotten from the questionnaires were presented in tabular forms. The Pearson product moment correlation coefficient was used to confirm formulated hypotheses which show the magnitude of the discrepancy between the variables, expectation and observation. The test was carried out at $0.5 \%$ level of significance using SPSS statistical tool.

Pearson correlation is represented as follows:

$$
\mathbf{R}=\mathbf{N} \Sigma \mathbf{X Y}-(\mathbf{X Y})(\boldsymbol{\Sigma} \mathbf{)}
$$

$\left.\left.\sqrt{[N} \mathbf{X Y} \mathbf{Y}^{2}-(\mathrm{X})^{2}\right] \sqrt{[N} \Sigma \mathbf{Y}^{2}-(\mathbf{Y})^{2}\right]$ 


\section{Data Analysis}

The results of the analysis based on the hypotheses tested are as shown below:

Table 1: Distribution and return of questionnaires

\begin{tabular}{clc}
\hline S/N & Option & Frequency \\
\hline 1. & Total Distributed & 120 \\
2. & Total Returned & 10 \\
\hline & Total Analyzed & $\mathbf{1 1 0}$ \\
\hline
\end{tabular}

Source: Field survey, (2021)

Table 2: Response on whether there has been a significant good effect on market prices since border reopened?

\begin{tabular}{cccccc}
\hline Option & Points & Response (y) & xy & $\mathrm{x}^{2}$ & $\mathrm{y}^{2}$ \\
\hline VR & 5 & 50 & 250 & 25 & 2,500 \\
$\mathbf{V}$ & 4 & 19 & 76 & 16 & 361 \\
$\mathbf{N E}$ & 3 & 1 & 3 & 9 & 1 \\
$\mathbf{I}$ & 2 & 20 & 40 & 4 & 400 \\
VI & 1 & 13 & 13 & 1 & 169 \\
& & & & & \\
\hline Total & $\mathbf{1 5}$ & $\mathbf{1 1 0}$ & $\mathbf{3 8 2}$ & $\mathbf{5 5}$ & $\mathbf{3 , 4 3 1}$ \\
\hline Source: & Research & computation, (2021). & Key: Very & Relevant & (VR), \\
Relevant(R), No Effect (NE) Irrelevant (I), and Very Irrelevant (VI). &
\end{tabular}




\section{Hypothesis 1}

$\mathrm{H}_{\mathrm{o}}$; There has been no significant good effect on market prices since border reopened

$\mathrm{H}_{1}$; There has been a significant good effect on market prices since border reopened

Here, using table 2 to answer to test hypothesis 1 . We apply the formula stated above;

$$
\begin{aligned}
& \mathbf{R}=\mathbf{N} \boldsymbol{N X Y}-(\mathbf{X Y})(\boldsymbol{\Sigma Y}) \\
& \sqrt{\left[\mathbf{N} X \mathbf{Y}^{2}-(\mathbf{X})^{2}\right]} \sqrt{\left[\mathbf{N} \Sigma \mathbf{Y}^{2}-(\mathbf{Y})^{2}\right]} \\
& =\frac{5(382)-(15 \times 110)}{\left[(5 \times 55)-(15)^{2}\right]\left[(5 \times 3431)-(110)^{2}\right.} \\
& =\frac{1,910-1650}{\sqrt{(275-225)(17155-12100)}} \\
& =\frac{260}{503} \\
& =0.52(52 \%)
\end{aligned}
$$

In hypothesis 1 , the $\mathrm{r}$ calculated of $0.52>0.5$ level of significance. The alternate hypothesis is accepted. This shows that there is significant good effect on market prices since border reopened compared to its closure in August 2019, which led to an inflation rate of $11.02 \%-15.75 \%$ by December 2020 as the 
highest rate recorded in three years. This implies that the prices of food items and other commodities that skyrocketed in the market during border closure are gradually being available at an affordable price.

The result agrees with the qualitative findings of Tony Onaharigho (2020) stating that reopening of the nation's land borders would facilitate the free flow and movement of goods into the country and in turn increase the market turnover and money in circulation.

Table 3: Response on whether border reopening has improved the economy of the country?

\begin{tabular}{cccccc}
\hline Option & Points & Response $(y)$ & $\mathrm{xy}$ & $\mathrm{x}^{2}$ & $\mathrm{y}^{2}$ \\
\hline VR & 5 & 60 & 300 & 25 & 3600 \\
V & 4 & 22 & 88 & 16 & 484 \\
NE & 3 & 10 & 30 & 9 & 100 \\
I & 2 & 1 & 38 & 4 & 1 \\
VI & 1 & 17 & 17 & 1 & 289 \\
& & & & & \\
\hline Total & $\mathbf{1 5}$ & $\mathbf{1 1 0}$ & $\mathbf{4 7 3}$ & $\mathbf{5 5}$ & $\mathbf{4 4 7 4}$ \\
\hline
\end{tabular}

Source: Researcher's computation (2020). Key: Very Relevant (VR), Relevant(R), No Effect (NE) Irrelevant (I), and Very Irrelevant (VI).

\section{Hypothesis 2}

$\mathrm{H}_{\mathrm{o}}$; border reopening has not improved the economy of the country.

$\mathrm{H}_{1}$; border reopening has improved the economy of the country. 
Here, using table 3 to answer to test hypothesis 2 . We apply the formula stated above;

$$
\begin{aligned}
& \mathbf{R}=\mathbf{N} \boldsymbol{N} \mathbf{X Y}-(\mathbf{X Y})(\boldsymbol{\Sigma Y}) \\
& \sqrt{\left.\left[\boldsymbol{N} \mathbf{X Y} \mathbf{Y}^{2}-(\mathbf{X})^{2}\right] \sqrt{[N} \Sigma \mathbf{Y}^{2}-(\mathbf{Y})^{2}\right]} \\
& =\frac{5(473)-(15 \times 110)}{\left[(5 \times 55)-(15)^{2}\right]\left[(5 \times 4474)-(110)^{2}\right.} \\
& =\frac{2,365-1650}{\sqrt{(275-225)(22,370-12100)}} \\
& =\frac{715}{717} \\
& =0.99(99 \%)
\end{aligned}
$$

In hypothesis 2 , the $\mathrm{r}$ calculated of $0.99>0.5$ level of significance. The alternate hypothesis is accepted. This shows that the economy is improving with the recent reopening of borders, businesses are back to normal reason being that people are moving in their goods and sell, and also produce and sell by having access to the markets that they used to patronise. Though the expected benefit has not manifested, the Nigeria government under the leadership of President Muhammadu Buhari needs to wax strong to keep situation under control so that the internal Gross Domestic Profit (GDP) reduction caused by border closure and Covid-19 outbreak doesn't drag the economy behind. 


\section{Findings}

At the end of this study, the following findings are made;

1. The alternate hypothesis is accepted showing that there is significant good effect on market prices since border reopened compared to its closure in August 2019, which led to an inflation rate of $11.02 \%-15.75 \%$ by December 2020 as the highest rate recorded in three years. This implies that the prices of food items and other commodities that skyrocketed in the market during border closure are gradually being available at an affordable price. The result agrees with the qualitative findings of Tony Onaharigho (2020) stating that reopening of the nation's land borders would facilitate the free flow and movement of goods into the country and in turn increase the market turnover and money in circulation.

2. In hypothesis 2 , the $r$ calculated of $0.99>0.5$ level of significance. The alternate hypothesis is accepted. This shows that the economy is improving with the recent reopening of borders, businesses are back to normal reason being that people are moving in their goods and sell, and also produce and sell by having access to the markets that they used to patronise. Though the expected benefit has not manifested, the Nigeria government under the leadership of President Muhammadu Buhari needs to wax strong to keep situation under control so that the internal Gross Domestic Profit (GDP) reduction caused by border closure and Covid-19 outbreak doesn't drag the economy behind. 


\section{Conclusion}

The study reveals that the recent border reopening is improving the Nigeria economy and gradually have good significant effect on market prices and in turn increase the marketing turnover.

\section{Recommendations}

The following recommendations are made;

1. This study recommends that there is need to strengthen the border policing and management mechanisms to avoid a relapse into the conditions that led to the closure in the first place.

2. Accountability need to be demanded from the institutions that have the responsibility for border policing and management.

\section{REFERENCES}

[1]. Ajayi, J.K., Ojalade, M.O., Sikiru, L., and Moabalaje, T. (2020). Assessment of Land Border closure on the Socio-economic Development of people in Saki Metropolis. International Journal of Innovative Development and Policy Studies 8(3):30-34

[2]. Akinkuolie, R. (2020). Nigeria's Border Closure: Pros, Cons and Consequences.https://www.google.com/amp/s/punchng.com/nigerias-border-closure-proscons-and-consequences/amp

[3]. Bukola, A. (2018).Nigeria Ranks Amongst Poorest Country https://edition.cnn.com/2018/06/26/africa/nigeria-overtakes-india-extreme-povertyintl/index.html

[4]. John, C. (2019). "Buhari's Orders Land Borders Closure in Long-Running Effort to Boost Rice Production" (CFR, 2019) https://www.cfr.org

[5]. Business Day, (2019). "Economics of Border Closure", Business Day Report. https://www.businessday.ng

[6]. Godwin, O. (2018). "Rice Remains A top the List of Items Smuggled into Nigeria" https://www.google.com/amp/s/www.vanguardngr.com/2018/09/rice-remains-atop-list-ofitems-smuggled-into-nigeria/amp/

[7]. Kelechukwu,I. (2021).Nigeria Reopens Land Borders to Trade. https://www.africa.business/2021/02/agribusinessmanufacturing/Nigeria-reopens-landborders-totrade Accessed 02/02/2021

[8]. Olatuji, G (2019). Border closure. https://vanguardngr.com/2019/11/border-closure-ourmembers-jobs-theatened-says-union-leader

[9]. Oluwasegun, O. (2019). Nigeria's Trade Sector Slumps into Recession amid Border Closure. https://www.businessday.ng

[10].Ryan, O. (2016). "What is Protectionism, and How Will it Affect your Wallet". https://www.singsaver.com Accessed 17/02/2020 
[11].Sanya, A. (2019). Nigeria's Economy Counts Gain of Border Closure. https://www.google.com/amp/s/tribuneonlineng.com/nigerias-economy-counts-gain-ofborder-closure/amp/

[12].Tony, O. (2020). Border reopening. http://nairametrics.com retrieved online 17/11/2020

[13].Wikipedia, (2019). 'Protectionism'. https://en.m.wikipedia.org Accessed 06/09/2019 